\title{
LEIBNIZ E A HISTÓRIA
}

Edmilson Menezes ${ }^{1}$

Resumo: Usualmente, entre nós, o autor da Monadologia não é estudado a partir de um interesse filosófico pela história; no entanto, suas preocupações intelectuais dirigem-se a essa área, e algumas filosofias da história tiveram os Essais de théodicée (1710) em seus horizontes, embora não houvesse Leibniz escrito uma teodicéia da história. O objetivo do trabalho é apresentar alguns prismas do pensamento leibniziano quanto àquele interesse, com destaque para o vínculo entre trajetória dos homens e embasamento teológico, de forma a compreender como estes dois elementos se articulam e justificam o otimismo enquanto marco analítico decisivo para uma ideia de história.

Palavras-chave: Leibniz - história - teologia - otimismo.

\section{Preâmbulo: as bases metafísicas da reflexão leibniziana sobre a história - o princípio da harmonia preestabelecida}

Existe uma disposição intrínseca ao ser humano, enquanto ser racional, que é a busca da verdade. O desejo pelo verdadeiro orienta o espírito no sentido de conduzi-lo à superação das dúvidas e incertezas que nele se fazem presentes. Nesse processo de superação de certa ininteligibilidade das coisas, a razão vai como que desvelando a aparente confusão do mundo, conferindo assim, clareza e sentido à realidade que o homem sente e percebe.

A capacidade que a razão tem de compreender como se dá tal desvelamento, a atitude crítica manifesta por meio da investigação profunda do real em toda sua complexidade estrutural, a análise das próprias possibilidades de se conhecer tal estrutura, enfim, essa inclinação do espírito pela verdade são elementos específicos da dimensão filosófica, portanto, metafísica, do saber humano. É precisamente nessa esfera que se configura todo itinerário de busca do conhecimento verdadeiro, traçado a partir do exame reflexivo que a razão empreende sobre si mesma, perfazendo-se quando, suprassumindo as dimensões subjetiva e objetiva da realidade, alcança um completo entendimento das coisas que podem ser conhecidas, assim como, uma pura racionalidade do sujeito capaz de conhecê-las. Diante disso, podemos indagar: é realmente possível que haja uma perfeita correspondência entre verdade e ser? Em que medida é o mundo completamente inteligível? Compreendê-lo como tal, implica dotá-lo, simultaneamente, de significado e realidade? Algo é verdadeiro porque existe ou o contrário, algo se efetiva quando a razão lhe confere sentido e verdade pelo

\footnotetext{
${ }^{1}$ Professor Titular do Departamento de Filosofia da Universidade Federal de Sergipe. Bolsista CNPq.
} 
processo cognoscitivo? A esse respeito é razoavelmente sensato pensar o argumento aristotélico que reconhece certa assimetria na relação entre a verdade e o ser; ora, é aquela que depende deste e não o inverso. Aristóteles coloca que não é por ser verdade que Sócrates é branco que Sócrates é branco, mas é por Sócrates ser branco que é verdade que ele é branco. ${ }^{2}$ Temos aqui uma nítida valorização do sensível no que se refere ao ato de conhecer a verdade das coisas.

Uma parcela significativa da modernidade filosófica toma um viés distinto daquele do estagirita na medida em que busca a causa da essência, da existência e das ações e reações de um ser naquilo que se denomina sujeito cognoscente. Ou seja, pensar o mundo e dizê-lo a partir da subjetividade é um signo distintivo da filosofia moderna. Nesse contexto, é possível aduzir o conhecimento subjetivo como sendo complementar à realidade objetiva, isto é, a relação entre verdade e ser, conhecimento e natureza não pode ser assimétrica, mas reciprocamente correspondente e complementar, pois é preciso reconhecer que o sujeito quer perceber e representar o real e este, por seu turno, dispõe-se naturalmente à percepção e à representação. Em última instância, conhecer verdadeiramente implica evidenciar as estruturas cognoscitivas do sujeito, na medida em que elas encerram verdades eternas e necessárias e, nesse aspecto, transpondo tais verdades para a realidade material, podemos estabelecer, por analogia, uma possível correspondência entre subjetividade e objetividade. É fundamental admitir, então, que existe uma inclinação da essência à existência, uma tendência das ideias e verdades inatas para a consciência objetiva das coisas, ou seja, o pensamento não se dirige ao mundo exterior sem voltar-se simultaneamente para si mesmo.

Para Leibniz, um dos principais expoentes da modernidade, a alma racional encerra o ser, a substância, o uno, o mesmo, a causa, a percepção, o raciocínio e uma série de outras noções que os sentidos não podem fornecer-nos ${ }^{3}$. Também admite, como é sobejamente conhecido, as ideias e verdades inatas. Elas estão sempre no espírito mas só se tornam propriamente avaliadas ao se converteremem objetos da apercepção, isto é, da consciência. Mas, deve-se acrescentar que as ideias e as verdades estão inatas em nós como inclinações, disposições, hábitos ou virtualidades naturais, e não como ações, embora tais virtualidades sejam sempre acompanhadas de algumas ações, muitas vezes insensíveis, que lhes correspondem ${ }^{4}$. Para o filósofo, o conhecimento tomado num sentido geral é mais do que a mera demonstração da necessária conexão e concordância, ou da oposição e discordância entre duas ideias. Com efeito, já se encontram no nosso intelecto tais ideias e é precisamente o conhecimento delas que nos capacita a discernir o necessário do contingente, o existente do puramente possível, ou o real do imaginário. Num sentido mais específico, enquanto conhecimento da verdade, conhecer implica perceber, além da ligação coerente das ideias entre si ou entre estas e as coisas, a própria razão daquilo que conhecemos ou experimentamos. Impõe-se, nesse aspecto, reconhecer "não poder algum fato ser tomado como verdadeiro ou existente, nem algum enunciado ser considerado verídico, sem que haja uma razão suficiente para ser assim e não de outro modo, embora frequentemente tais razões

${ }^{2}$ Cf. LOPES DOS SANTOS, "Leibniz e os futuros contingentes", p. 95. Ver também ARISTOTE, La Métaphysique, t. I, p. 207 (1007 a20-b10).

${ }^{3}$ LEIBNIZ, Nouveaux essais sur l'entendement humain, Livro II, Cap. I, p. 70.

${ }^{4}$ Cf. Id. Ibid., Introdução. 
não possam ser conhecidas por nós." ${ }^{5}$ Este enunciado nos remete ao princípio da razão suficiente que, junto com o princípio da contradição, constituem os fundamentos dos nossos raciocínios. O principal mote, isto é, os objetos específicos dos nossos raciocínios, são os atos de reflexão, aos quais chegamos pela apreensão das verdades necessárias e suas abstrações. Conceber tais verdades a partir de um exame reflexivo é o que constitui o conhecimento das realidades básicas e do universo como um todo.

O autor dos Novos Ensaios compreende o universo, na sua totalidade, como um complexo dinâmico composto por entidades dotadas de um princípio de força e capazes de engendrar o movimento que constitui a efetividade ${ }^{6}$; tal força ou vigor permanece sempre, a despeito da mudança, passando apenas de matéria em matéria. Apesar dessa complexidade, o dinamismo do universo não é desordenado, pois obedece a uma determinada lógica racional expressa na cadeia de razões que oferece a causa da essência, da existência, das ações e reações dos seres, conforme as leis da natureza e a ordem preestabelecida. Ora, deve haver uma série causal ou uma cadeia de razões que organize e determine o ser e a verdade. Sendo assim, como esse encadeamento tende ao infinito, o ideal seria atingir uma "causa primeira", "causa incausada", ou seja, Deus ${ }^{7}$. Com isso, ter-se-ia uma razão suficiente de si mesma e de toda realidade efetiva. Portanto, na dinâmica da natureza percebe-se uma total relação entre as coisas, no sentido de que parece haver um "enlace de todas as coisas criadas a cada uma e de cada uma a todas as outras(...)" ${ }^{\prime \prime}$ construindo um universo harmonicamente perfeito. Essa harmonia lógica da natureza está circunscrita na própria unidade substancial constitutiva do real.

A lei serial que liga as mônadas entre si chama-se harmonia preestabelecida; ela consiste no fato de que Deus, por sua vontade e sua sabedoria, conduziu o ser das mônadas de tal modo que as percepções de cada uma delas, a cada instante, reagindo entre si, distinguem-se das outras pelo ponto de vista que cada mônada tem do universo, ou seja, por seu grau de clareza, de inteligibilidade. Deus, ao regular o todo, atendeu a cada parte e muito em especial a cada mônada, cuja natureza representativa nada conseguiria limitar à representação de uma só parte das coisas, muito embora, na verdade, esta representação seja confusa apenas nos detalhes de todo o universo, e distinta apenas em pequena parte das coisas, ou seja, ou nas mais próximas ou nas maiores, relativamente a cada uma das mônadas; de outra forma cada mônada seria uma divindade. As mônadas são, por isso mesmo, não limitadas no objeto, mas na modificação do conhecimento do objeto. Todas tendem confusamente para o infinito, para o todo, mas os graus das percepções distintas as limitam e distinguem. A harmonia preestabelecida quer dizer, pois, que Deus, ao criar cada mônada, leva em consideração todas as outras; a vontade de criar uma mônada particular com todos os acontecimentos que disso decorre não é jamais um decreto primitivo ou absoluto; não há vontade solta em Deus; mas, tendo querido o melhor dos mundos possíveis, Ele deu a cada uma das substâncias toda a perfeição possível; acontece que seu decreto em relação a uma

5 LEIBNIZ, "Monadologie”, §32, p. 249.

6 Ver LEIBNIZ, "Monadologie", \$\$7 e 8, p. 244.

7 Id. Ibid. $₫ 38$ e segs., p. 251.

8 Id. Ibid. \56, p. 254. 
substância particular, ou a um acontecimento dessa substância, é sempre um decreto exhypothesi resultante de uma ordem universal.

A harmonia preestabelecida permite explicar em que sentido (puramente ideal) uma mônada age: numa mônada, da qual todo o ser é representativo, a ação designa uma passagem a um degrau superior de inteligibilidade e a paixão, a passagem a um grau inferior. Ora, em virtude da harmonia, o aumento de inteligibilidade em uma mônada tem por correlativo necessário a diminuição de inteligibilidade em uma ou em várias outras; podemos dizer, então, (idealmente) que a primeira age sobre as segundas. Um caso particular dessa interação é posto em evidência a propósito do problema da união entre corpo e alma: entre a alma e o corpo não existe influência real, como o queria Descartes ${ }^{9}$, mas harmonia preestabelecida, como entre dois relógios tão bem regulados por seu fabricante que eles continuarão indefinidamente a marcar a mesma hora um e outro. Essa independência e essa espontaneidade não impedem que, de uma maneira ideal, possamos falar de uma interação, no seguinte sentido: o que é ação em um, corresponde uma paixão no outro e vice-versa.

Na pré-ordenação divina as vias da natureza estariam de acordo com aquelas da graça:

Assim, estando persuadido, aliás, do princípio da harmonia em geral e, por conseguinte, da perfeição e da harmonia preestabelecida de todas as coisas entre elas, entre natureza e graça, entre os decretos de Deus e nossas ações previstas, entre todas as partes da matéria, e mesmo entre o futuro e o passado, o todo conforme à sabedoria imperante de Deus, cujas obras são as mais harmônicas que se possa conceber; eu não poderia deixar de conduzirme a esse sistema que estabelece que Deus criou a alma, inicialmente, de tal modo que ela deve se produzir e se representar ordenadamente o que se passa no corpo; e o corpo também de tal modo que ele deve fazer de si mesmo o que a alma ordena. ${ }^{10}$

As perfeições da alma, assim como as da natureza, são, por assim dizer, "emanações" das perfeições divinas sobre o universo. Leibniz permanece de acordo com a ideia que estabelece: tudo se faz mecanicamente na natureza. Mas crê que os próprios princípios da mecânica, isto é, as leis da natureza, em relação à força movente, procedem de razões superiores e de uma causa imaterial que faz tudo de maneira a mais perfeita. As percepções grandes e notáveis provêm por graus daquelas que são excessivamente insignificantes para serem notadas. Não concordar com isso é o mesmo que afirmar o desconhecimento da imensa sutileza das coisas, que envolve um infinito atual, em toda a parte e sempre. O que se esconde não deixa de existir por isso: "Porém", diz Leibniz, "existe, nos tesouros da sabedoria divina, isto é no Deoabscondito, e, o quer dizer o mesmo, na harmonia universal das coisas, uma grandeza secreta que lhe faz considerar como melhor e como preferível a todas as outras a série universal atual, compreendendo os acontecimentos que nós admiramos e os julgamentos que nós veneramos." ${ }^{11}$

9 Cf. LEIBNIZ, “Monadologie”, §80, p. 260.

10 LEIBNIZ, "Essais de théodicée", §62, p. 146.

11 LEIBNIZ, "Essais de théodicée”, La cause de Dieu, \$142, p. 460. 
Com efeito, o universo é composto de substâncias imateriais, análogas às almas, das quais somente uma espécie, a dos espíritos, é dotada de reflexão. Essas substâncias imateriais estão, como já afirmamos, unidas entre si não por causalidade física, mas por causalidade ideal, mediante relações reguladas, graças às quais se intercomunicam e constituem juntas uma harmonia universal perfeita, na qual a simplicidade das vias é igual à riqueza dos efeitos. ${ }^{12}$ Nada, nem mesmo os milagres nem a graça, estão ausentes à ordem. Para Leibniz, os atos de cada substância foram antecipadamente regulados, de maneira que estejam de acordo com todos os atos de todas as outras substâncias: "E é isso que faz com que, representando cada uma dessas substâncias exatamente todo o universo à sua maneira e segundo certo ponto de vista, e ocorrendo as percepções ou expressões das coisas externas na alma no momento preciso em virtude de suas próprias leis, como em um mundo à parte e como se não existisse nada além de Deus e da alma, haja um perfeito acordo entre todas essas substâncias." ${ }^{13}$ A interação entre as substâncias, por conseguinte, tem unicamente em Deus a sua razão a priori; e não poderia ser de outra forma se entendermos, com Leibniz, que estamos tratando de um conceito primitivo (Deus), do qual se estrutura todos os conceitos derivados (harmonia):

Um conceito primitivo (...) é um conceito que não pode ser reduzido a outro, porquanto o objeto a que se refere não apresenta outras características, senão que se manifesta somente por meio de si mesmo (sed est index sur). Um conceito assim só pode dar-se com respeito àquela coisa que é conhecida por si mesma, quer dizer, com respeito à substância suprema, ou seja, Deus. Todos os conceitos derivados que podem chegar a formar-se só podem ser adquiridos por meio desse conceito primitivo, de tal sorte que nas coisas nada existe senão por ação de Deus e em nosso espírito não se pode nada pensar senão por meio da ideia de Deus, embora não possamos chegar a conhecer com absoluta claridade de que maneira brotam de Deus as naturezas das coisas ou como emanam as ideias das coisas da ideia de Deus, no que teria, aliás, de consistir em última análise o conhecimento adequado de todas as coisas em virtude de sua causa. ${ }^{14}$

É graças a essa harmonia que os pontos de vista de cada substância sobre o mesmo universo formam um todo coerente, é graças a essa harmonia que, por exemplo, as modificações de minha alma e os movimentos de meu corpo concordam como dois relógios que marcassem a mesma hora. A harmonia universal desemboca no sumo poder e na sabedoria divinos: “(...) tudo o que Deus faz é harmonicamente perfeito."15 Aquele corpo é

${ }^{12 C f . ~ B E L A V A L, ~ Y ., ~ " L e i b n i z ” . ~ I n: ~ H i s t o i r e ~ d e ~ l a ~ p h i l o s o p h i e . ~ P a r i s: ~ G a l l i m a r d, ~} 1973$.

${ }^{13}$ LEIBNIZ, "Sistema novo da natureza e da comunicação das substâncias", p. 26-27.

${ }^{14}$ LEIBNIZ, Opuscules et fragments inédits de Leibniæ, p. 513.

${ }^{15}$ LEIBNIZ, "Essais de théodicée", \$74, p. 151. Pode-se, pois, dizer que através da ideia de Deus e da noção de harmonia temos acesso privilegiado ao sistema, além disso, esses elementos da filosofia de Leibniz justificariam sua preocupação, por exemplo, com a unificação das igrejas. Sem dúvidas, a harmonia permanece a suprema verdade metafísica. Nela acabam se fundindo as diversidades que pareciam irredutíveis, que se agrupam num todo onde cada uma tem seu lugar, de acordo com a ordem estabelecida por Deus. Tudo se passa, nos lembra Paul Hazard, como se o universo fosse um 
orgânico, quando forma uma espécie de autômato ou de máquina da natureza, que é máquina não somente no todo, mas ainda nas menores partes que podem se fazer notar. Por causa da plenitude do mundo tudo está ligado, e cada corpo age sobre cada outro corpo, mais ou menos, segundo a distância, e é por ele afetado por relação; segue-se que cada mônada é um espelho vivo, dotado de ação interna, representativo do universo, segundo seu ponto de vista, e tão regulado quanto o próprio universo. Desta forma, as percepções nas mônadas nascem umas das outras pelas leis dos apetites ou das causas finais do bem ou do mal, que consistem nas perfeições notáveis, reguladas ou desreguladas, como as mudanças dos corpos e os fenômenos de fora nascem uns dos outros pelas leis das causas eficientes, ou seja, dos movimentos. "Assim, há uma harmonia perfeita entre as percepções das mônadas e os movimentos dos corpos, preestabelecida desde o início entre o sistema de causas eficientes e o das causas finais. Nisto consiste o acordo e a união física da alma e do corpo, sem que uma possa mudar as leis do outro." ${ }^{16}$

Deus age não só fisicamente, mas, ainda, livremente. Nele não está somente a causa eficiente, mas também o fim de todas as coisas; em resumo, Deus não manifesta unicamente sua grandeza e poder na máquina do universo já construída, mas, também, sua bondade ou sabedoria no plano de sua construção. Deve-se atentar para aideia de que o mundo não é apenas o mais perfeito fisicamente, ou bem, se se prefere, metafisicamente, porque ele contém a série de coisas que apresenta o máximo de realidade em ato, porém, ele é ainda o mais perfeito possível moralmente, pois a perfeição moral é, com efeito, para os espíritos eles mesmos, uma perfeição física: "Donde se segue que o mundo é não só uma máquina deveras admirável; mais ainda: ele é, enquanto composto de espíritos, a melhor das repúblicas, aquela que lhes dispensa as maiores felicidade e alegria possíveis, consistindo nessa felicidade a perfeição física dos espíritos." ${ }^{17}$ No entanto, pode-se dizer que é justamente o contrário que encontramos no mundo: para os bem intencionados, com frequência, as coisas vão mal; não são só os animais inocentes, mas também os homens inocentes, são sobrecarregados de diferentes malefícios, atingidos, as vezes, com uma extrema crueldade, de forma a que o mundo pareça, sobretudo se consideramos os destinos do gênero humano, antes assemelhado ao caos que a uma obra bem ordenada, fruto de uma sabedoria superior. Essa, contudo, não passa de uma avaliação guiada apenas pela primeira aparência, e com ela, arrastamos em nosso exame o seu caráter superficial e célere. Entretanto, ao examinarmos as coisas mais de perto, impõe-se a opinião contrária.

Leibniz evoca o princípio jurídico que diz: é, sem dúvidas, injusto julgar antes de haver examinado a lei por inteiro; e, dessa forma, argumenta a favor da estabilidade harmônica no mundo. Nós conhecemos somente uma parte ínfima da eternidade que se prolonga na imensidade; pois os milhares de anos registrados pela História, são, na verdade, "pouca coisa". E, no entanto, é de acordo com essa experiência mínima que julgamos temerariamente a imensidade e a eternidade; julgamentoassemelhado ao de homens que,

grande coro, “o indivíduo tem a ilusão de nele cantar sozinho o seu canto mas, na realidade, ele faz somente seguir por sua conta uma imensa partitura, na qual cada nota foi colocada de tal modo que todas as vozes se correspondem e formam um concerto mais perfeito do que a harmonia das esferas." (HAZARD, La crise de la conscience européenne, p. 207).

16LEIBNIZ, "Principes de la Nature et de la Grâce", §3, p. 224.

${ }^{17}$ LEIBNIZ, "De la production des choses", p. 185. 
nascidos e instruídos numa prisão, creem não haver no mundo outra luz senão aquela da rústica lamparina que ilumina seus claudicantes passos. Olhemos, insiste Leibniz, um belo quadro e o cubramos em seguida, de sorte que reste somente uma minúscula parte. O que veremos nela, mesmo examinando-a muito proximamente, mesmo quando dela nos aproximamos mais e mais, senão certo amontoado confuso de cores, feito sem escolha e sem arte? E, todavia, ao levantarmos o véu e olharmos o quadro por inteiro da distância conveniente, compreenderemos o que tinha antes um ar de tarefa feita ao acaso sobre a tela como revelador efeito da arte perfeita de um pintor. É a priori certo que todas as coisas, e com a mais forte razão os espíritos, recebem a maior perfeição possível. ${ }^{18}$

Segundo o filósofo, "toda substância é como um mundo completo, como um espelho(...) de todo o universo(... $)^{19}$ ”. Nessa perspectiva, poder-se-ia dizer que a razão pode conhecer as causas da realidade natural a partir da apreensão da configuração substancial das coisas. Estando a essência compreendida nas ideias e, como estas residem no espírito, é possível estabelecer um nexo entre espírito e natureza, razão e existência. A possibilidade de compreender e explicar o mundo parte da nossa capacidade de abstrairmos e nos elevarmos ao conhecimento dessa ligação, à intuição das ideias inatas, das verdades necessárias e dos princípios racionais. Como exemplo de um destes princípios, um dos principais para se entender sua teoria do conhecimento, Leibniz assinala:

Ora, por esse único princípio, a saber, que é preciso haver uma razão suficiente pela qual as coisas são antes assim do que de outro modo, demonstra-se a divindade e o resto da metafísica ou da teologia natural, e mesmo de certa maneira os princípios físicos independentes da Matemática, isto é, os princípios dinâmicos, ou da força. ${ }^{20}$

Portanto, a percepção reflexiva ou a ação de conhecer como as outras coisas podem ser percebidas não é uma visão, nem um sentimento ou uma imaginação, mas uma investida que o espírito empreende sobre si mesmo, buscando encontrar, assim, as razões a priori da determinação das coisas. Como vimos, apenas as mônadas racionais têm esse caráter reflexivo. Nesse sentido, “as Mônadas são limitadas não no objeto, mas na modificação do conhecimento do objeto. Todas tendem confusamente para o infinito, para o todo, mas os graus de Percepções distintas as limitam e distinguem." ${ }^{21}$

O fato de o espírito ou alma racional poder refletir-se e, com isso, ascender, gradativamente, à plena racionalidade garante, apesar dessa inclinação ao infinito, certa compreensão e certa consciência da finitude, dos limites do próprio espírito no tocante ao conhecimento dos fenômenos. Seguramente, o alvo que a alma racional pretende atingir é a perfeição. Nesse aspecto, é preciso também, conhecer o que é a perfeição, o que é o Ser Perfeito; em outros termos, é necessário que se apreenda as razões da existência da Mônada Infinita. A possibilidade de conhecermos o que é Perfeito, de conhecermos aquilo que

18Ib. Ibid.

${ }^{19}$ LEIBNIZ, "Discours de métaphysique", IX, p. 214.

20 LEIBNIZ, Correspondência com Clarke, p. 172.

${ }^{21}$ LEIBNIZ, "Monadologie", \$60, p. 255. 
constitui causa de si mesmo e de todas as coisas, nos torna superiores aos outros seres. Nesse sentido, impõe-se outra importante distinção entre as mônadas ordinárias e os espíritos: "as Almas em geral são espelhos vivos ou imagens do Universo das criaturas, mas os Espíritos são ainda imagens da própria Divindade, ou do próprio Autor da natureza, capazes de conhecer o sistema do universo (...)" ${ }^{22}$.

Cumpre ainda destacar que o conhecimento do universo, nesse contexto, não está atrelado simplesmente a uma investigação empírica dos fenômenos, ou seja, não parte da mera observação sensível da natureza. Ora, sendo a percepção o elemento específico da teoria do conhecimento em Leibniz, a atividade perceptiva e, na mesma linha, a atividade reflexiva, correspondem a uma ação intuitiva. Percebemos a realidade intuitivamente; o ser racional reconhece aquilo que se lhe manifesta pela percepção intelectual. Contudo, podemos ter também percepções sensíveis. Isso conduz Leibniz a reconhecer duas espécies de verdades, as de razão e as de fato. As primeiras são necessárias e o seu oposto impossível, já as últimas são contingentes e o seu oposto possível. Todavia, como não devemos partir da contingência à necessidade, mas sim, da razão última e necessária das coisas para explicar a existência, infere-se: o conhecimento metafísico possui um valor maior do que o conhecimento sensível. $\mathrm{Na}$ "representação arquitetônica" do entendimento divino - esfera das verdades eternas e ideias necessárias - vislumbramos o fundamento da realidade possível e atual, do que é e daquilo que pode vir a ser, conforme a ordem necessária da natureza. Assim, pensar na ideia de Deus, da essência, do infinito, da verdade; enfim, conceber as ideias fundamentais como asseguradoras de todo conhecimento e percepção racionais, a partir de uma breve apreciação da Monadologia, nos leva a concluir que, em Leibniz, todo conhecimento depende da Metafísica, mais especificamente da ideia de Deus, porquanto, segundo o filósofo: "não há qualquer outro objeto externo agindo em nossa alma e excitando imediatamente a nossa percepção. Temos assim em nossa alma as ideias de todas as coisas apenas devido à contínua ação de Deus sobre nós, quer dizer, pela razão de todo efeito exprimir sua causa, e por isso a essência da nossa alma é uma expressão, imitação ou imagem da essência, pensamento e vontade da divindade e de todas as ideias compreendidas nela." ${ }^{23}$ Essa ideia de Deus corresponde a uma formulação sistemática que integra a possibilidade de uma harmonia cosmológica detectada e entendida como racional.

A filosofia de Leibniz, em última análise,permanece baseada nesta ideia nuclear: tudo nas diversas substâncias acontece em conformidade com leis internas próprias a cada uma delas, estando, entretanto, em função do engenho do criador divino, as modificações ocorridas em cada substância em perfeita concordância com o que ocorre em todas as outras, podendo, portanto, cada substância ser tomada como um espelho a refletir, a partir do ponto de vista característico dessa substância, a totalidade do universo. Desse modo, apesar da autonomia absoluta de cada substância, o universo pode emergir como uma totalidade cujas partes estão tão harmonicamente dispostas que se tem a impressão de haver uma acomodação mútua entre elas, produzida por interações causais. Entretanto, uma vez que interações desse tipo acarretariam uma, por assim dizer, perda de substancialidade das substâncias em questão, resta somente, então, que essa harmonia seja preestabelecida por

22 LEIBNIZ, “Monadologie”, §83,p. 261.

${ }^{23}$ LEIBNIZ, "Discours de métaphysique”, §XXVIII, p. 242-243. 
Deus quando da criação do mundo. ${ }^{24} \mathrm{~A}$ harmonia envolve todo o universo até o seu mais ínfimo detalhe, onde o melhor se estabelece como conexão. A temporalidade, desde então, é integrada no encadeamento dos acontecimentos.

\section{Leibniz: teologia e história}

Para uma considerável parte da inteligência do século XVII, a verdade teológica deve ser reatualizada com a incumbência de preencher a indeterminação motivada pelo descomedimento da razão. ${ }^{25}$ Nesse âmbito, a filosofia precisa estar sob a prevenção e a aliança teologal.

A teologia fornecerá os preceitos encarregados da redefinição de vários ramos da cultura do espírito. A filosofia e a história, sob o escudo teológico, ajustam-se mais uma vez em vista do combate às intimidações apontadas à tradição cristã. Um leitor de Descartes apresentará novo impulso ao diálogo entre filosofia e história: fujamos ao isolamento do Cogito; existem outros espíritos como nós, e o comércio entre os espíritos é confirmado pela história sagrada e pela história profana:

(...) porque é preciso que todos os que existam tenham um comércio entre si, é preciso, também, que isso tenha uma causa e, além do mais, que todos exprimam a mesma natureza, porém, de diversas maneiras; ora, a causa que faz com que todos os espíritos tenham um comércio entre si, ou exprimam a mesma coisa, e existam, é aquela que traduz perfeitamente o universo, a saber, Deus. Essa causa não tem causa, e é única. Donde, de imediato se conclui que existe uma pluralidade de espíritos como o nosso; e como não é difícil pensar que os homens com os quais lidamos podem encontrar o mesmo tanto de causas para duvidar de nós, como nós deles, e que nenhuma razão mais forte milita em nosso favor, eles também existirão e terão espíritos. É assim que nos mantemos para confirmar a história sagrada e a história profana, com tudo aquilo que respeita à condição dos espíritos ou substâncias racionais. ${ }^{26}$

Com efeito, a história nos instrui a compreender a jurisprudência, a trajetória dos romanos, a abarcar o direito civil, a vida eclesiástica, a dominar o direito canônico, as organizações da idade média, a abranger o direito feudal, a era moderna e a fazer uso do direito público. Eis alguns exemplos, mesmo que sucintos, de como a história pode nos propiciar componentes importantes para a compreensão das instituições humanas. A história não é um simples objeto de curiosidade, nem possui como tarefa a trivial coleção de fatos; ela tem por alvo nos mostrar os diversos fundamentos da composição das sociedades, nos conduzir às suas origens - e aqui reside o seu ponto principal. Todavia, haverá um impasse

${ }^{24}$ MARQUES, “Apresentação”, p. 11.

${ }^{25}$ Cf. GUSDORF, G., "L’homme des Lumières”, p. 26. Ver também: HAZARD, La crise de la conscience européenne.

${ }^{26}$ LEIBNIZ, "Comment distinguer les phénomènes réels des imaginaires", p.197. 
quando chegarmos a essas origens, se tentarmos compreendê-las nelas mesmas: uma indeterminação ou uma incerteza tomará conta do raciocínio. Ao contrário, ao subordinarmos o intento histórico a princípios ordenadores, cuja evidência nem sempre é observada instantaneamente, não só as origens, mas o desenvolvimento do mundo e das instituições ganha maior inteligibilidade. Existe certa sabedoria, uma espécie de ciência que nos governa, mesmo nas inseguranças, para descobrir de que lado encontra-se a maior aparência. No entanto, diz Leibniz ${ }^{27}$, é espantoso que ela seja quase desconhecida e que os Lógicos não tenham examinado, ainda, os graus de probabilidade ou de verossimilhança existentes nas conjecturas ou provas que possuem, não obstante, seu valor também assegurado, igualmente aos números; esse valor pode e deve nos servir não para chegarmos a uma certeza, o que é impossível, mas para agirmos o mais razoavelmente que se possa diante dos fatos ou conhecimentos a nós fornecidos. Isso permite compreender o universo como um intricado conjunto eficaz formado por forças capazes de gerar o movimento que compõe a realidade; tais forças conservam-se sempre ocorrendo apenas segundo a disposição das matérias. Logo, o universo não é caótico, porque satisfaz a uma lógica racional expressa na cadeia de razões que oferece o motivo das ações e reações dos diversos seres, consoante a uma ordem preestabelecida. Com efeito, divisa-se uma série causal que constitui e define o ser e a verdade;esse encadeamento tende ao infinito.O ideal, portanto, seria atingir uma "causa incausada" 28 ,ou seja, razão suficiente de si mesma e de todo fato real. Na totalidade da natureza percebe-se uma profunda e inteira relação entre os acontecimentos, um universo harmonicamente completo. Essa harmonia lógica encontra-se adstrita à própria unidade substancial característica do verdadeiro e do real.

A criação revela-se sob os auspícios e decretos divinos; eles se dirigem aos movimentos voluntários das substâncias inteligentes, que Deus quis criar, considerando o que elas quereriam e fariam em diferentes circunstâncias e situações, nas quais Ele poderia colocá-las, a fim de tomar uma resolução conveniente. Em outros termos, Deus, ao criar o mundo, levou em consideração não apenas critérios lógicos, mas, igualmente, princípios morais. Assim, uma providência é perfeitamente justificada: "com toda a certeza, é o fundamento da Providência e de todas as nossas esperanças saber que existe algo de bom e de justo nele mesmo, e que Deus sendo a própria sabedoria não falha ao escolher o melhor." ${ }^{29}$ A providência, enquanto um princípio organizador, permite-nos reagrupar, analiticamente, o que parece confuso na história e nela encontrar estabilidade e sabedoria. Para Leibniz, a história demonstra a providência de Deus e a verdade do cristianismo: os "conhecimentos Históricos (...), por assim dizer, nos permitem penetrar nos segredos da Providência", como as ciências propriamente ditas nos fazem "conhecer as grandezas da sabedoria divina." ${ }^{, 30}$ Não podemos, com riqueza de detalhes, conhecer os desígnios da

27 LEIBNIZ, "Nouvelles ouvertures", p. 226-227.

28 LEIBNIZ, "Monadologie”, §38 e segs., p. 251.

29 LEIBNIZ, "Leibniz a Philippi, 01/168”, Die philosophischen Schriften (Band IV), p. 284.

30 LEIBNIZ, "Nouvelles ouvertures", p. 226. Em outra passagem, Leibniz afirma: "Finalmente, o que há de mais em harmonia com a piedade do que as obras de Deus e da Providência, cuja apreciação nos maravilha, as quais não são menos importantes na natureza das coisas, tampouco na sucessão da história e no governo da Igreja, mas resplandecem na raça humana?" (LEIBNIZ, "Leibniz a Magliabechi, 2/05/1692", Opera omnia (Tomo V), p. 99). 
providência, entretanto, temos a possibilidade de afirmar - e provar, se for necessário, pela física e pela biologia - que seus fins dirigem o mundo. A razoabilidade penetra os caminhos da providência histórica, assegurando-lhe, pelo recurso à lógica e à filosofia, uma dignidade intelectual dantes não vislumbrada. "Com o autor da Teodicéia, a filosofia permanece uma auxiliar da teologia." ${ }^{31}$ Contra Descartes, ele aceita que a fé não contradiz a razão, que a filosofia não pode se desinteressar da teologia, e que a história tem uma função apologética.

A história, em colaboração com a filosofia e a jurisprudência, possui um papel no terreno da teologia que concerne aos fatos. "A História da Antiguidade é de uma necessidade absoluta para a prova da verdade da religião e, colocando à parte a excelência da doutrina, é por sua origem divina que a nossa se distingue de todas as outras." ${ }^{32}$ Não se pode ter um melhor uso da história do que dá testemunho sincero às grandes verdades contidas nos antigos autores, desde que exatamente verificados - eis o papel da investigação; "e, se os maometanos e os pagãos, e mesmo os libertinos, não se rendem à razão, pode-se dizer que é, principalmente, pelo erro de não saberem história antiga, assim, aqueles que a ignoram por inteiro são sempre crianças, do mesmo modo como aquele egípcio, que fala a Sólon, julgou os gregos ${ }^{33}$." 34

A história sagrada dos cristãos, que se difere das demais, pois, além de santa, é, também, racional, torna-se o núcleo para o qual convergem todas as demais histórias. $\mathrm{O}$ irresistível influxo da razão que interpreta a história confere maioridade àqueles que a ela se submetem e, ao mesmo tempo, transformam-se em intérpretes dos seus princípios maiores. As verdades e consequências teológicas, possuidoras de uma certeza moral e não metafísica, "supõem, em parte, a história e os fatos, e, em parte, a interpretação dos textos. Mas, para bem se servir dessa história e desses textos, e para estabelecer a verdade e a antiguidade dos fatos, o caráter genuíno e a divindade de nossos livros sagrados, e mesmo a antiguidade eclesiástica, e, enfim, o sentido dos textos, é preciso ainda recorrer à verdadeira filosofia

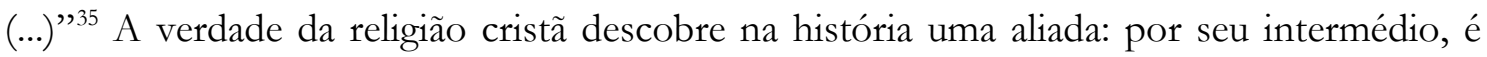
possível enfrentar os opositores do Cristo, assim como, sustentar as verdades da fé. Leibniz reconhece a importância da história humana, e das artes e ciências que dela dependem: a história universal dos tempos, a geografia dos lugares, a investigação das antiguidades e das diversas coisas que trazem consigo testemunhos, como condecorações, inscrições, manuscritos etc.; o conhecimento das línguas, a filologia, a etimologia; ajunte-se, ainda, a literatura, por meio da qual se aprende o progresso dos conhecimentos, as notícias, das quais se precisa para verificar o que outros já pensaram, e a jurisprudência. Não obstante, as múltiplas possibilidades oferecidas pelo estudo histórico podem levar, ademais, ao risco de nos colocar num emaranhado de subsídios e informações, cuja saída é difícil. É imperioso que haja um escopo específico a guiar o historiador ou o leitor das antiguidades, a fim de que seu esforço convirja para um resultado proeminente.

\footnotetext{
31 BELAVAL, Leibniz critique de Descartes, p. 110.

32 LEIBNIZ, "Nouvelles ouvertures", p. 226.

33 PLATÃO, "Timée", 22b.

${ }^{34}$ LEIBNIZ, "Nouvelles ouvertures", p. 226.

35 LEIBNIZ, “Leibniz a Th. Burnett, 01/02/1697”, Die philosophischen Schriften (Band III), p. 193.
} 
O maior uso do conhecimento das Antiguidades e das línguas mortas é aquele que se tira para a Teologia, tanto no que toca a verdade da Religião Cristã e a autoridade dos Livros Sagrados, como para explicar esses livros e dirimir suas dificuldades, e para conhecer, enfim, a doutrina e a prática da Igreja de Deus e as leis ou cânones da jurisprudência divina. ${ }^{36}$

A religião e a teologia serão as fontes das quais o historiador se servirá para orientar seu discernimento dos elementos a seres comprovados, avaliados ou investigados. O intuito volta-se à utilização de todo o manancial técnico do seu ofício em proveito da fé: qual sentido outro poderia conceder relevância ao seu trabalho? Fora do raio de influência da fé, tudo parece menor e irrelevante. Da ciência mais abstrata à mais concreta, da matemática à história, tudo proclama a verdade divina, tudo pede a atenção do sábio.

A história da salvação, parâmetro para todas as outras, é a mais importante, pois, enquanto história da religião cristã, ocupa-se da proclamação, no tempo, das verdades reveladas por Deus e assumidas pelos crentes. "O uso da História será apenas entretenimento, caso não esteja ali demostrada a verdade da religião cristã, o que só pode ser feito por meio das histórias." ${ }^{37}$ Tomando por base essa referência, pode-se, então, instituir com segurança a serventia da história: "O uso da história consiste, principalmente, no prazer do conhecimento das origens, na justiça atribuída aos homens que bem mereceram, no estabelecimento da crítica histórica e, sobretudo, da história sagrada que sustenta os fundamentos da revelação." ${ }^{38}$ Se Descartes, que toma a matemática como único modelo, não tivesse sido levado, pela sistematização da dúvida, a opor tão nitidamente verdade e erro, se tivesse praticado a diplomacia e a jurisprudência, teria aprendido a estimar a verdade do provável. Lá, onde ele só vê um tecido de fábulas, poderia ter descoberto que o conjunto das antiguidades "serve não só à satisfação dos curiosos, mas bem antes para a conservação e aprumo da história, cujos exemplos são lições vivas e instruções agradáveis, mas, principalmente, para estabelecer essa importante Crítica, necessária para discernir o imaginado do verdadeiro e a fábula da história, e da qual o recurso é admirável para as provas da religião." ${ }^{39}$ Como Descartes ignorou a verdadeira história, diz Belaval ${ }^{40}$,não soube nela reconhecer o espelho da providência, nem uma moral oculta - Historia Divinae providentia especulum est Deumque nobis moralitate quadam vestitum exhibet -: as verdades tiradas da matéria parecem mostrar a presença de Deus, a imensa amplitude das ideias que emanam de sua essência, mas a história civil, na qual é preciso comportar a história sagrada, parece mostrar a exuberante vontade de Deus,

${ }^{36}$ LEIBNIZ, "Mémoire de 1692", Schriften und Briefezur Geschicbte, \$18, p. 68.

${ }^{37}$ LEIBNIZ, "Leibnitiana. Sive Meditationes, Observationes \& Crises variae Leibnitianae Gallico \& Latino sermone expressae", Opera omnia (Tomo VI), p. 297.

38 LEIBNIZ, Nouveaux essais sur l'entendement humain, 1. IV, cap. XVI, p.419. "Tais antiguidades somente podem ter uso sólido para a história e para servir ao esclarecimento da Santa Escritura." (LEIBNIZ, "Leibniz a Th. Burnett, 22/11/1695", Die philosophischen Schriften (Band III), p. 166).

${ }^{39}$ LEIBNIZ, "Scientia Generalis. Characteristica (X - Discours touchant La Méthode de la Certitude et l'Art d'Inventer)", Die philosophischen Schriften (Band VII), p. 175.

${ }^{40}$ BELAVAL, Leibniz critique de Descartes, p. 117. 
"porque a História é o espelho da Divina Providência e nos apresenta Deus revestido de certa moralidade, na medida em que se mostra não apenas como o princípio das coisas, como na Metafísica e na Matemática, e admirável inventor de máquinas, como na física, mas, igualmente, Rei dos Espíritos nesta República Universal; também é quase como um dos nossos, ou seja, um Espírito melhor provido de razão e, por isso, revelou, no que diz respeito a nós, sua imensa bondade para a humanidade no governo dos Impérios e na defesa da Igreja, mas especialmente na Economia da nossa salvação." ${ }^{41}$

A história da humanidade possui um sentido, ela exprime a verdade. Sem dúvida porque não abarcamos sua totalidade, há para nós uma desordem, uma confusão: "Há, certamente, mil desregramentos, mil desordens no particular. Mas não é possível que eles se encontrem no todo, mesmo de cada mônada (...) não é possível que o universo inteiro não seja bem ordenado, a prevalência em perfeição sendo a razão de existência desse sistema de coisas, preferentemente a todo outro sistema." ${ }^{42}$

Não importa o prazer que se possa tirar da história, o seu uso dirige-se para a demonstração teológica e sua verdade máxima, isto é, a existência de Deus e a imortalidade da alma. Pela história, pode-se remontar, numa sequência de demonstrações teológicas, ao Cristo tornado homem no tempo e à proclamação dessa verdade inalienável:

Pois, enfim, o que há de maior e que interessa mais aos homens do que a religião? Não é infinitamente agradável, infinitamente consolador, aprender com certeza, no meio das misérias da vida, que somos nascidos para a imortalidade, e para uma imortalidade conforme podemos desejar, quer dizer, tal como Jesus Cristo nos ensinou? Provar que ele é o Messias reparador do gênero humano, anunciado por tantos oráculos, é, após a demonstração da existência de Deus e da Imortalidade da alma, a mais importante de todas as conclusões; e não vejo qual maior vantagem possamos esperar da história e da erudição. Digo mais: o estudo da Antiguidade não me parece ter quase nenhum outro uso, do que nos colocar em condições de constatar e de conservar fielmente os antigos títulos de nossa felicidade e, se assim posso me exprimir, de nossa nobreza, que devemos, após nossa regeneração pelo batismo, fazer remontar a Cristo. É preciso provar, de início, que nossos livros sagrados são autênticos e que chegaram até nós sem nenhuma alteração substancial. (...) É preciso mostrar, em seguida, que o autor de tão grandes coisas, e ao qual se reportam os livros sagrados, foi enviado pelos céus. (...) Mas, não podemos demonstrar que todas essas coisas se passaram da forma como as contamos sem termos estabelecido solidamente toda a história universal, sagrada e profana; e para estabelecê-la solidamente é preciso a coleção de manuscritos, de medalhas, de inscrições e de todas as outras peças

41 LEIBNIZ, "Scientia Generalis. Characteristica (VIII - Specima Initiis Scientiae generalis addenda)", Die philosophischen Schriften (Band VII), p. 139.

${ }^{42}$ LEIBNIZ, “Leibniz à Remond, 11/02/1715”, Die philosophischen Schriften (Band III), p. 635-636. 
que compõem o tesouro dos sábios. Pois é daí que a história tira seus títulos de crença (...)". Enfim, "o principal alvo de todo o estudo da Antiguidade deve ser o esclarecimento (éclaircissement) e a confirmação da história sagrada. ${ }^{43}$

Uma "verdadeira filosofia" não pode dar as costas à teologia ${ }^{44}$ e, tampouco, desprezar as lições da história ${ }^{45}$, como fez Descartes:

A verdadeira filosofia deve nos fornecer toda uma outra noção da perfeição de Deus que nos possa servir em física e em moral, e entendo, bem longe de querer excluir as causas finais da consideração física, com pretende o Senhor Descartes, ser , antes, por meio delas, que tudo deve se determinar, pois a causa eficiente das coisas é inteligente, tendo uma vontade e, por conseguinte, tendendo ao bem, o que ainda se distancia do sentimento do Senhor Descartes, que entende que a bondade, a verdade e a justiça somente existem porque Deus as estabeleceu por um ato livre de sua vontade. O que é bem estranho. Pois, se as coisas só são boas ou más por um efeito da vontade de Deus, o bem não será um motivo de sua vontade, porque ele é posterior à vontade. E sua vontade será um certo decreto absoluto sem razão. ${ }^{46}$

A ordem e a perfeição encontradas no universo espelham a absoluta bondade de Deus, para quem a totalidade do que existe se remete do começo ao fim de tudo. Tomada em seu aspecto dinâmico, a unidade da criação engendra sua continuidade, pois o mundo das ideias, que lhe fornece o arquétipo, é dinâmico. Com a criação do melhor dos mundos possíveis que nasce de suas combinações, essa tensão se desenvolve no tempo, ou antes, se exprime para nós em um desenvolvimento temporal. Esse tempo é contínuo. A sucessão dos homens não é mais uma sucessão incoerente de indivíduos independentes; a sucessão de seus pensamentos não é mais a simples justaposição de reflexões livres uma das outras. ${ }^{47}$ Dessa forma, a continuidade histórica oferece algo de racional, e ela se desvelaria como inteiramente racional se nos fosse possível, como a Deus, ver na menor substância exprimir-se a ligação de todas as substâncias em seus estados presente, passado e futuro. Portanto, tudo se encadeia, tudo se harmoniza num mundo escolhido entre os melhores possíveis e que aceita o progresso. Nada na história é indiferente ou isolado; o detalhe dos acontecimentos pode ter uma importância estimável, assim como a representação desse detalhe na ordem da produção.

A nova perspectiva filosófica também confiará à relação entre história e erudição um novo uso, possibilitando, desse modo, reconhecer um espaço destacado na busca dos verdadeiros desígnios e do verdadeiro agente da história: "Eu já posso", diz Leibniz, "felicitar

43 LEIBNIZ, “Démonstration Évangelique de M. Huet: lettre à Huet, 1679”, Pensée de Leibniž sur la religion et la morale, t. I, p. 165-166.

44 Cf. DESCARTES, “Lettre à Mersenne, 27 mai 1630”, CEurres de Descartes (Tome I), p. 153.

45 DESCARTES, "Recherche de la Verité”, Euvres de Descartes (Tome X), p. 502-503.

46 LEIBNIZ, "Leibniz a Philippi”, Die philosophischen Schriften (Band IV), p. 284.

47 BELAVAL, Leibniz critique de Descartes, p. 113. 
a erudição que, enfim, encontrou (...) seu verdadeiro uso" ${ }^{48}$; decerto, "o maior de todos os usos da erudição consiste no serviço à religião." 49 Tais usos podem ser justificados pela convergência entre teologia, filosofia e história, e seu esforço em colocar o discurso histórico dentro de uma ordem e de uma concatenação capazes de lhe conferir sentido. Esse expediente não encontrará tal unidade num princípio deduzido da própria razão, numa evidência metafísica independente de qualquer elemento externo. A demonstração dessa coesão é racional, visto ser o espírito a fornecer a chave de compreensão ao empírico, porém, ela fará da razão apenas o instrumento para justificar o elemento supra-histórico capaz de impor unidade à história, sem outorgar ao sujeito individual abstrato a autoridade do comando da realidade.

Entre a história particular, natural, empírica, e a história universal há uma cisão que se explica pelo entendimento de que a segunda só pode ser escrita por Deus, conhecedor $a$ priori de tudo o que acontecerá à primeira; a história empírica, dominada pela apreensão humana, somente é conhecida a posteriori. Essa dimensão da história, porque estribada em verdades de fato, estará submissa, em última análise, às verdades de razão. Por isso mesmo, a história empírica não pode ser alçada a objeto de reflexão filosófica; ela é apenas erudição e, nesse grau, não pode, por si só, ser capaz de levantar problemas ao espírito, não pode afetálo verdadeiramente. $\mathrm{Na}$ verdade, o espírito lhe fornece os mecanismos de assimilação a partir de um parâmetro ordenado por uma grande cadeia causal que tem sua origem numa causa incausada, numa razão absoluta, da qual tudo é dependente. A história conhecida pelo homem leva, em muitas ocasiões, ao desespero e ao pessimismo. Para assimilar esse báratro, ele deve recorrer à racionalidade que afirma, pelo princípio do melhor dos mundos possíveis, a história em desenvolvimento num trilho preparado segundo a razão divina. A história avaliada pelo homem não é a mesma distinguida por Deus e, entre as duas, a certeza de que estamos no que é o melhor historicamente. ${ }^{50}$ Se os fatos podem nos enganar, se neles há apenas confusão e verdade aparente, um princípio racional, lógico e metafisicamente estruturado nos garante o desvio do erro no julgamento da história:

Sob este governo perfeito [o de Deus] não haverá boa ação sem recompensa nem má ação sem castigo e tudo deve convergir para o bem dos bons, isto é, daqueles que não estão insatisfeitos com este grande Estado, que confiam na Providência - após terem feito seu dever - e amam e imitam, convenientemente, o Autor de todo o bem, regozijando-se na consideração de suas perfeições segundo a natureza do verdadeiro puro amor, que faz encontrar prazer na felicidade daquilo que se ama. É o que faz trabalhar as pessoas sábias e virtuosas em tudo quanto parece conforme a vontade divina presuntiva ou antecedente e se contentar, no entanto, com o que Deus nos faz chegar efetivamente pela sua vontade secreta, consequente e decisiva, reconhecendo que, se pudéssemos bem entender a ordem do universo,

${ }^{48}$ LEIBNIZ, "Démonstration Évangelique”, Pensée de Leibniz sur la religion et la morale, t. I, p. 166.

${ }^{49}$ LEIBNIZ, "Scientia Generalis. Characteristica (IV - Initia et Specimina Scientiae novae Generalis)", Die philosophischen Schriften (Band VII), p. 70.

${ }^{50}$ LEIBNIZ, "Discours de Métaphysique”, §VIII. 
acharíamos que ela ultrapassa todas as intenções dos mais sábios e que é impossível de torná-lo melhor do que é, não só para o todo em geral, mas, também, para nós próprios em particular, se estamos unidos, com convém, ao Autor de tudo, não somente como Arquiteto da causa eficiente de nosso ser, mas, ainda como nosso Mestre e causa final que deve ser o alvo de toda a nossa vontade e único a poder fazer nossa felicidade. ${ }^{51}$

A filosofia e a história deixam de fixar-se em zonas contrárias: se antes a história, considerada uma disciplina dependente e duvidosa, não conseguia granjear de um pensamento, cuja ambição era fundar a Mathesis Universalis, a declaração de critério de cientificidade $^{52}$ agora ela integra-se a uma filosofia que busca entender como o princípio do melhor opera efetivamente na atualização do mundo, permitindo uma harmonia geral. A realidade efetiva é produzida a partir do possível, numa unidade íntima entre o poder e a sabedoria de Deus. O amálgama que une a filosofia e a história só pode ser compreendido, por consequência, pela associação à teologia - setor ao qual ambas se submetem. Enquanto guardiã de verdades superiores inatingíveis pela razão, a teologia ocupa importante lugar interpretativo e permite que à sucessão dos homens seja facultado um espaço de significação. O Deus da Bíblia está parcialmente oculto; seus projetos e objetivos detalhados escapam ao homem. O filósofo reconhece a distinção entre o que vai contra a razão e o que está acima dela. Do ponto de vista humano, não há tensão entre razão e fé. Se a fé afirma a verdade dos objetos que a razão não pode avançar com certeza, ela não pode, pelo contrário, influenciar elementos expressos e demonstrativamente negados pela razão. Entre os componentes da mensagem bíblica revelada, uma parte é imediatamente idêntica, recuperável sem ajuste pela metafísica racional. Por exemplo, a existência de um Deus único, todo bem, todo poderoso, onisciente e eficiente causa do mundo não é menos confirmada pelo Pentateuco e pelos Evangelhos do que pelas provas racionais às quais Leibniz dá seu aval e desenvolve numa série de versões. Essas verdades, diz ele na Teodicéia, são "tão filosóficas quanto teológicas." 53

Contrariamente a Descartes, que deixa de lado qualquer tipo de importância maior a ser atribuída à história, a tentativa leibniziana é a de reorganizar a produção do saber histórico colocando-o a serviço da religião. Ao fazer convergir teologia, filosofia e história, a primazia é, indiscutivelmente, da primeira, isto é, os elevados interesses da teologia fazem com que as demais ciências a ela se conformem, de tal modo, que a totalidade do discurso histórico será sustentada a partir de um conjunto de referências retiradas do aparato religioso e teológico. A filosofia, como expressão de um empenho da inteligência para articular a compreensibilidade do real enquanto totalidade, requer um concurso que vai além daquele interesse, porque se arbitrou que a autoridade teológica era cogente,justamente,por dar conta de um dos problemas candente da reflexão filosófica, a saber, a estrutura da existência humana consiste, essencialmente, em uma tensão entre um último plano eterno e um primeiro plano temporal, de tal sorte que o ponto de partida temporal da existência implica um distanciamento de sua origem, um esquecimento do próprio princípio. Falar de Deus não

51 LEIBNIZ, "Monadologie”, $\$ 90$.

52 Cf. DESCARTES, “Lettre à Hogelande, 08 février 1640”, CEuvres Philosophiques (Tome II), p. 159.

53 LEIBNIZ, “Essais de théodicée”, \109, p. 172. 
significa, nesse contexto, alusão a um tema específico, técnico mas a tudo o que é verdadeiro, à unidade do cosmos, à realidade em seu conjunto. A teologia reagrupa o disperso no tempo, confere-lhe unidade e fornece a medida para o instrumental analítico responsável por interpretar as marcas visíveis do invisível tornado histórico.

\section{Ordenamento moral e inteligente do mundo: otimismo e progresso}

A doutrina leibniziana do otimismo já se encontra presente no Discurso de Metafísica (1686), no entanto, sua forma mais lapidada, mais sistematicamente disposta, localizamo-la nos Ensaios de Teodicéia (1710). O problema lá exposto pertence a uma profunda essência metafísica: como justificar a presença do mal físico, do mal moral, já que Deus apresenta-se como o princípio do bem enquanto perfeição infinita? $O$ pecado e a fraqueza dos homens são suficientes para explicá-lo (o mal), visto colocarem em relevo os limites do poder divino, que não pôde impedir suas criaturas de errar, devido à ambiguidade nelas inseridas e manifesta em sua possibilidade de propensão ao mal? Leibniz desenvolve uma resposta teórica e prática destinada a prevenir a queda no ceticismo ou no pessimismo. O pressuposto é o da tendencial perfeita transparência entre o mundo e a razão humana. Isso ocorre porque "o direito universal é o mesmo para Deus e para os homens." 54

Foi através da explicitação das potencialidades dessa identidade matricial entre o direito divino e o humano que Leibniz se lançou ao clássico enigma acerca de como podemos compreender a aparente contradição entre o mal patente nas criaturas e a suma bondade do princípio unitário da criação. Para ele, entre a nossa razão e os mais insondáveis mistérios da existência não há uma barreira qualitativa, um fosso, mas tão somente uma diferença de grau e quantidade. Assim sendo, é possível, para o entendimento humano, penetrar especulativamente os desígnios da criação, na íntima ordem do universo. Uma reivindicação dessa natureza exige um preço bastante alto. A nossa reconciliação intelectual com a presença fenomênica do mal no mundo, a plena aceitação deste como objeto da força e geração divinas, decreta uma diminuição da liberdade humana sob a tutela de uma organização ontoteológica do universo - base para o estabelecimento de uma teodicéia. A própria economia da totalidade impeditiva da manutenção de uma concepção substancial do mal vai retirar à decisão humana o peso de uma plena responsabilidade. "Nós estabelecemos que o livre arbítrio é a causa próxima do mal da culpa, e em seguida do mal do sofrimento; embora seja verdadeiro que a imperfeição original das criaturas que se encontra representada nas ideias eternas é a primeira e mais remota causa daqueles." ${ }^{55}$ Se o homem, quando age, sabe que, em última instância, a sua liberdade não é mais do que uma simples causa próxima do bem ou do mal moral, analogicamente Deus tem de permitir, então, a presença do mal residual, como o sinal da melhor escolha possível, porque a lógica global do existente não só não pode suprimir as manifestações parcelares do mal, do aparentemente contrário a um fim, como tem de as admitir necessariamente.

${ }^{54}$ LEIBNIZ, "Essais de théodicée", \$35, p. 79.

${ }^{55}$ LEIBNIZ, "Essais de théodicée”, \$288, p. 297. 
Mas quando se trata de um crime, Deus somente pode querer permiti-lo: o crime não é nem fim nem meio, é só uma condição sine qua non; dessa forma, ele não é objeto de uma vontade direta (...). Deus não o pode impedir sem agir contra aquilo a que está subordinado, sem fazer algo que seria pior que o crime humano: violar a regra do melhor; o mesmo seria destruir a divindade (...). Deus é, portanto, obrigado por uma necessidade moral, nele próprio encontrada, a permitir o mal moral das criaturas. ${ }^{56}$

Deus não pode se dispensar da escolha sem fazer uma falta; e antes mesmo de perpetrar algo semelhante, o que lhe é de todo inconveniente, Ele permite a falta ou o pecado do homem - previsto na combinação que faz deste o melhor dos mundos.

Inexoravelmente, o problema da teodicéia levaria Leibniz a estabelece a priori que a providência reina, embora isso não deva antecipadamente incitar a inatividade, por meio de três formas de destino que se diferenciam, antes de qualquer coisa, pelas suas conclusões: o fatum mahometanum, que ensina a resignação; o fatum stoïcum, determinismo que ensina a paciência; e o fatum christianum que, em virtude de professar a providência, produz o contentamento. ${ }^{57}$ Em resumo, podemos dizer que o problema do mal segue, em Leibniz, duas grandes orientações: a) tudo está bem no melhor dos mundos possíveis porque o mesmo foi criado por um Deus benevolente - embora esse mundo não seja perfeito em todos os seus detalhes; b) o mal existe, isso é certo, mas é negligenciado ao olharmos a soma total do bem produzido, ele é a condição de um bem futuro maior e mais global. Em virtude de sua natureza perfeita, Deus não criou, nem poderia criar senão o melhor dos mundos possíveis: "A sabedoria infinita do Todo Poderoso, associada à sua imensa bondade, fez com que, ao fim das contas, nada de melhor pudesse ter sido criado a não ser o que foi criado por Deus." 58 A ideia de mundo é aquela de um conjunto coordenado de seres e acontecimentos passados, presentes e futuros. ${ }^{59}$

Em cada variante do mundo, cada possível é examinado em seus nexos necessários ou contingentes com os outros, no seio de uma grande engrenagem na qual tudo se corresponde. Bastaria que um elemento (uma propriedade, um acontecimento, um ser) fosse modificado para que tivéssemos outro mundo. Fruto de um cálculo infinito, a escolha de criar o mundo existente obedeceu a dois princípios reconhecidos pelo entendimento humano. Primo, o de não contradição. Deus tinha diante de si a infinidade de mundos possíveis caracterizados cada um por pelo menos um elemento diferente dos outros. Com efeito, se ele devia escolher era, primeiramente, porque a realização de cada possível está submetida a esse princípio lógico absoluto. Este delimita um campo de verdades eternas (lógicas e matemáticas) cuja negação é contraditória - o centro de um segmento não pode não pertencer a esse segmento ou não ser equidistante de suas extremidades, senão ele não pode ser definido com um segmento - assim como um domínio de fatos contingentes, na medida em que cada ocorrência, se ela se produz, exclui toda e qualquer outra possível para

56 LEIBNIZ, "Essais de théodicée”, \$158, p. 213.

${ }^{57}$ LEIBNIZ, "Essais de théodicée”, Préface, p. 36-37.

58 LEIBNIZ, "Essais de théodicée”, La cause de Dieu, \$46, p. 442.

${ }^{59}$ Cf. MALKASSIAN, Candide: un débat philosophique - La critique de Leibnizpar Voltaire, p. 18. 
o lugar que ela ocupa na cadeia: João, de uma só vez, não pode ser e não ser mortal; um metal não é capaz de, ao mesmo tempo, se dilatar e se contrair. É, portanto, logicamente impossível que todos os possíveis possam se realizar num mesmo mundo. ${ }^{60}$ Eles se distribuem numa quantidade infinita de mundos possíveis, isto é, de cada combinação realizável de um complexo infinito de compossíveis, de acordo com o limite imposto pelo princípio de não contradição.

Secundo, Deus recorre, para efetuar sua escolha entre as variantes, a outro princípio, a saber, aquele da razão suficiente. "Nada acontece sem que para isso concorresse uma causa, ou, ao menos uma razão determinante, ou seja, alguma coisa que possa fornecer uma razão a priori para que algo seja existente antes que não existente e para que algo seja assim antes que de maneira diversa." ${ }^{61}$ Esse título subordina aquele da causalidade - segundo o qual cada acontecimento é o efeito irreversível ao menos de uma causa - ao da finalidade - ou seja: à consideração de um bem, objetivo e global para todo o universo quando se trata de Deus, parcial e subjetivo (em aparência) quando se trata das criaturas racionais (cujas representações conformam-se conscientemente a esse princípio, mesmo que de maneira incorreta) que está na origem da produção de todo o acontecimento. O princípio da razão suficiente legisla sobre as propriedades contingentes: se Deus escolheu a existência das variações num mundo possível, ele o decidiu em função de considerações finalistas. A sabedoria divina, não contente em abarcar todos os possíveis, os penetra, os compara, os mede uns em relação aos outros, para assim estimar os graus de perfeição ou de imperfeição, o forte e o fraco, o bem e o mal; ela vai além das combinações finitas ao se ocupar de uma infinidade de infinitos, quer dizer, de uma infinidade de sequências possíveis do universo, onde cada uma contém uma infinidade de criaturas; e por esse meio, a sabedoria divina distribui todos os possíveis - que havia antevisto no começo - entre os diversos sistemas universais, por ela ainda comparados entre si: e o resultado de todas essas combinações e reflexões é a escolha do melhor entre todos os sistemas possíveis, que a sabedoria realiza para satisfazer a bondade, justamente o plano vigente no universo atual. ${ }^{62}$ Resultado: cada elemento está ligado indiretamente a todos os outros, por meio de uma conexão única. O mundo deriva de uma estrita necessidade e tudo nele se passa segundo um determinismo absoluto concebido segundo a sabedoria divina: "Ela fez com que todas as coisas fossem perfeitamente harmônicas e conspirassem, em conjunto, para o mais belo acorde." ${ }^{63}$

Se, enfim, tudo está encadeado necessariamente e disposto para o melhor, então disso segue-se, inevitavelmente, uma moral: a aceitação tranquila dos acontecimentos. Queridos por Deus, eles são independentes de nossa vontade, donde certo fatalismo. Estabelece-se, desse modo, uma crença num destino, numa espécie de encadeamento único e não modificável de causas e efeitos dirigido para o bem, donde um providencialismo. A finalidade regente da obra criada introduz uma providência geral e particular que doa a cada acontecimento, a cada decisão uma necessidade condicional sob a forma de previsibilidade

\footnotetext{
60 LEIBNIZ, “Essais de théodicée”, §44, p. 136.

61 Id. Ibid.

${ }^{62}$ LEIBNIZ, "Essais de théodicée”, \$225, p. 261.

${ }^{63}$ LEIBNIZ, "Essais de théodicée”, La cause de Dieu, \46, p. 442.
} 
em si infalível. Ela certifica o mundo da condição do melhor dos mundos possíveis, progressivamente realizado em cada um dos seus elementos.

O princípio da providência divina, jungido ao determinismo absoluto, faz, consequentemente, do otimismo leibniziano uma teoria do progresso inelutável dos homens na história. ${ }^{64}$ No plano temporal, o mal existente é a condição de um arranjo ótimo do mundo, embora o filósofo não admita uma evolução do universo. É preciso considerar que há uma imperfeição original nas criaturas, mesmo antes do pecado. Elas são essencialmente limitadas, disso decorre que podem enganar-se e cometer uma série de outros erros. De acordo com Leibniz, podemos tomar o mal em três acepções: o mal metafísico consiste na simples imperfeição, o mal físico no sofrimento e o mal moral no pecado. Ora, conquanto o mal físico e o mal moral não sejam necessários, é suficiente que em virtude de princípios racionais eles sejam possíveis. E como essa região imensa de verdades (expressas pelos princípios) contém todas as possibilidades, é preciso que haja uma infinidade de mundos possíveis, que o mal entre em vários deles, e que mesmo o melhor de todos eles disso não possa escapar, é o que determinou Deus permitindo o mal. ${ }^{65}$ Se o mal pertence aos homens como uma disfunção natural ou um escândalo ético, isso não passa de uma aparência: todos esses desvios derivam dos mecanismos instaurados por Deus para assegurar, com o mínimo dos meios, a ordem máxima das coisas e o maior bem-estar dos indivíduos. O mal é, pois, real. É a expressão física ou moral de uma insuficiência absoluta que corresponde, por sua vez, aos limites mundanos da coexistência dos fatos e a uma espécie de inércia das criaturas, impedindo-as, por meio de uma resistência passiva, de integrar o conjunto das determinações infinitas que lhes destina Deus.

A perfeição é atribuída pelo Criador às criaturas, todavia uma perfeição limitada pela receptividade própria de cada uma delas: "Assim, o entendimento se equivocará com frequência por defeito de cautela, a vontade se cindirá por defeito de prontidão, todas as vezes que o espírito, que deve estender-se a Deus, quer dizer ao Bem supremo, se ativer por inércia às criaturas." ${ }^{66}$ Efetivamente, Deus não quer o mal, o permite, entretanto, como um tributo a pagar pelo melhor dos mundos possíveis. Enfim, a ideia de criação implica num otimismo fundamental, segundo o qual tudo o que é, não importa em que grau, é semelhança de Deus e o mal na história apresenta-se como decorrência de um plano moral para os homens; “(...) o mal serve, frequentemente, para saborearmos melhor o bem, e, algumas vezes, contribui para uma maior perfeição daquele que sofre, tal como um grão semeado sujeito a uma espécie de corrupção para germinar: uma bela comparação da qual o próprio Jesus se serve." ${ }^{\prime 67}$ A atenção dada ao nexo natureza e espírito torna indissociável o devir físico e o progresso moral das almas; espiritualidade e natureza se encontram, coisas e seres imateriais desenvolvem-se em direção a uma plenitude sempre ascendente.

${ }^{64}$ Cf. MALKASSIAN, Candide: un débat philosophique - La critique de Leibnizpar Voltaire, p. 24.

${ }^{65}$ LEIBNIZ, "Essais de théodicée", \$21, p. 124.

${ }^{66}$ LEIBNIZ, "Essais de théodicée", La cause de Dieu, \$73, p. 447.

${ }^{67}$ LEIBNIZ, "Essais de théodicée", \$23, p. 125. A alusão bíblica refere-se a: "amen amen dico vobis nisi granum frumenti cadens in terram mortuum fuerit" (João 12, 24). 
Usualmente, entre nós, o autor da Monadologia não é estudado a partir de um interesse filosófico pela história; no entanto, suas preocupações intelectuais dirigem-se a essa área ${ }^{68}$, e algumas filosofias da história tiveram os Essais de théodicée (1710) em seus horizontes, embora não houvesse Leibniz escrito, como lembra Binoche, uma teodicéia da História. "Com efeito, é permitido propor que, para uma grande parte, os filósofos do século seguinte pensaram a história como uma (anti) teodicéia, seja porque a tenham descrito como uma cena de espoliação perpétua - como Voltaire no Ensaio sobre os costumes -,seja porque ali tenham visto a realização imanente e progressiva do melhor dos mundos - herança da qual Hegel teve, lucidamente, consciência." "V9 Vale sublinhar que o recorte escolhido da obra de Leibniz para ser analisado não é prioritariamente aquele dos textos do historiógrafo ${ }^{70}$, do erudito; mas importa destacar alguns princípios filosóficos leibnizianos que passarão, em definitivo, a fazer parte da discussão posterior sobre a história.

Há, para o filósofo, uma clara diferença entre a via descritiva dos fenômenos ou dos seus agentes e aquela dos princípios que alimentam as ações: "A maior parte dos outros, mais versados na Antiguidade do que na arte," diz Leibniz em carta a Thomasius, "nos mostraram os caminhos de pensadores mais do que os pensamentos eles mesmos, embora que, vós procurais uma história, não de filósofos, mas da filosofia." 71 Uma taxionomia para a história pode ser algo bastante útil, mas, do mesmo modo, pode a filosofia fornecer uma gama de conceitos capaz de orientar aquele que se põe ante à história e, dessa maneira, o que foi particularmente classificado pode ser melhor compreendido ao apresentar-se inserido numa universalidade:

Para fazer a História de Bronsvic, que possa ter a aprovação dos conhecedores, precisaria pensar em juntar bons materiais e lhes dá uma forma que faça jus à beleza e à grandeza da matéria. (...) Eu procurarei fazê-lo pelo estilo, pela exatidão com respeito aos relatos e por algumas descobertas Históricas pouco conhecidas, que terei o cuidado de fazer entrar, e que atingirão o universal, embora tenham nascido da História particular. ${ }^{72}$

A passagem do particular ao universal exige uma mediação, que Leibniz irá buscar no já assinalado princípio da harmonia entre as duas instância, de forma a entender aquilo que se passa na terra como provindo de uma estreita necessidade.

O interesse de Leibniz para a filosofia da história radica, em última instância, em sua formulação acerca do otimismo. Mesmo que seja para combatê-lo ou para dialetizá-lo, a

68 A esse respeito, cf. DAVILLÉ, L. Leibniz, historien: essai sur l'activité et la méthode historiques de Leibniæ: Paris: Félix Alcan, 1909.

69 BINOCHE, "Les histoires d'avant l'histoire", p. 12. Ver também: Les trois sources des philosophies de l'histoire (1764-1798), Terceira parte. Paris: PUF, 1994.

70 Sobre as obras de historiografia, cf. LEIBNIZ. Gesammelte Werke: Geschichte. Hildesheim: Georg Olms Verlagsbuchhandlung, 1966.

${ }^{71}$ LEIBNIZ, "Leibniz à Thomasius, avril 1669". In: Leibniz - Thomasius Correspondance 1663-1672. Trad. de R. Bodéüs. Paris: Vrin, 1993.

72 LEIBNIZ, "Histoire de Bronsvic", Schriften und Briefe zur Geschichte, p. 840. 
posteridade filosófica que elabora uma ideia de história dele não pôde se esquivar. ${ }^{73}$ Contudo, o crédito atribuído por Leibniz ao progresso, ao mesmo tempo progresso do saber, progresso moral, movimento em direção a uma civilização superior realizando, de uma só vez, a unidade dos homens e, desse fato, a felicidade e a paz, pode resumir o que habitualmente chamamos o seu otimismo ${ }^{74}$ Seria o caso, se o devir, ele mesmo, fosse realizador, se ele tendesse simplesmente em direção a um fim último mais elevado, ou se ele devesse melhorar a ordem existente. Tal foi a leitura que, no século XVIII, teriam feito os adversários de Leibniz. ${ }^{75} \mathrm{O}$ que afirma Leibniz é que este mundo é o melhor dos mundos possíveis, não que ele virá a ser; portanto, o otimismo é uma reflexão racional a priori cujo princípio é o pensamento da criação como decisão divina única de fazer existir o universo, não somente na realidade dada, como, da mesma forma, em todo o seu desenvolvimento. Mas, é preciso também lembrar que Deus não teria escolhido o melhor se o mundo se desenvolvesse sem progresso ${ }^{76}$. Esse progresso possui duas fontes: a perfeição implicada na noção completa de melhor dos mundos possíveis e que deve se atualizar no tempo; e a inquietude, essencial à consciência, que impele à busca do prazer, signo da perfeição.

Não se pode querer, sem mais, transformar Leibniz num Aufklärer avant la lettre e, em consequência, transpor para o seu pensamento o que será o otimismo histórico presenciado nas filosofias da história posteriores. Mas, isso não autoriza afirmar a ausência de uma meditação leibniziana sobre o progresso universal. Com efeito, uma preocupação com a perfeição possível conduz o sistema ao irremediável interesse pelo progresso:"E mesmo, para acrescentar à beleza e à perfeição universal das obras divinas, é preciso reconhecer um progresso perpétuo e absolutamente ilimitado de todo o universo, de modo que ele marche sempre em direção a uma maior cultura (cultum)." ${ }^{.77}$ Ainda no mesmo parágrafo ele diz:

Embora seja verdadeiro que, de tempos em tempos, alguma parte retorne ao estado selvagem, ou seja destruída ou submergida, é necessário, entretanto, considerar tal fato como nós interpretamos, anteriormente, as aflições, quer dizer, essa destruição, ou essa submersão, fazem progredir em direção a alguma consequência superior de modo que, de qualquer forma, ganhe-se com o dano. ${ }^{78}$

A originalidade de Leibniz, segundo Courtès ${ }^{79}$, reside numa concepção monista das coisas:

É uma verdade certa que cada substância deve alcançar toda a perfeição de que é capaz, e que já se encontra nela como envolvida (...) É por isso que elas avançam e amadurecem perpetuamente como o próprio mundo, do qual são

\footnotetext{
73 Cf. BELAVAL, Leibniz critique de Descartes, p. 128; DELBOS,La philosophie pratique de Kant, p. 264.

${ }^{74}$ COURTÈS, "La conception leibnizienne du progrès", p. 41.

75 Id. Ibid.

76 Cf. BELAVAL, Leibniz critique de Descartes, p. 114.

77 LEIBNIZ, "De rerum originatione radicali”, Euvres choisies, $\$ 16$.

78 Id. Ibid.

${ }^{79}$ COURTÈS, "La conception leibnizienne du progrès", p. 34.
} 
as imagens; pois, como não há nada fora do universo que possa impedi-lo, é preciso que o universo avance continuamente e se desenvolva. ${ }^{80}$

Sustentada pela linguagem renovada da ciência, essa concepção substancial abre, sob os olhos dos filósofos, um panorama absolutamente original do futuro dos homens, condicionado por sua ação prática, sempre ligado a seu passado. A alma jamais se desfaz de suas percepções passadas, de modo que, ainda que passe por um período de obscurecimento, está sempre além do que já foi ${ }^{81}$ :

Ou poderemos dizer que o mundo cresce necessariamente em virtude, porque as almas são afetadas por todas as coisas passadas? De fato, já mostramos (...) que não há nas almas um esquecimento perfeito; mesmo se nossa lembrança não é distinta, tudo que percebemos no presente consiste em partes em que se integram todas as ações anteriores. ${ }^{82}$

E, é preciso acrescentar, toda essa estrutura metafísica se consubstancia numa história que está atrelada à marcha secreta de uma providência que não impõe um caminho linear ao cumprimento dos desígnios divinos.

Para melhor compreender essa originalidade, é forçoso, inicialmente, desembaraçar a noção de progresso de alguns de seus significados usuais, quer dizer, não crer que progredir é passar de um estado inferior a um estado superior segundo uma ordem cronológica ou juntar a uma parcela adquirida uma nova conquista, ou ainda dirigir-se para um estado de perfeição completa.

Ainda agora", propõe Leibniz, "grande parte de nossa terra vem recebendo cultura e continuará a recebê-la (...). Também temos uma resposta à possível objeção de que, assim sendo, há muito que o mundo teria se tornado um paraíso. Apesar de muitas substâncias já terem atingido uma grande perfeição, no entanto, devido à infinita divisibilidade do contínuo, sempre haverá, no abismo das coisas, partes que dormem e que ainda deverão ser acordadas para crescer em tamanho e em mérito e, em resumo, para avançar na direção de um estado mais perfeito. (...) E assim o fim do progresso jamais será alcançado. ${ }^{83}$

O progresso não é nem um crescimento quantitativo, nem um avanço submetido à ordem efetiva do tempo, nem a aproximação de um alvo privilegiado, menos ainda a passagem da desordem à ordem, ou a simples acumulação de novidades: nem adição, nem composição mecânica, nem ordem linear. No texto Apokatástasis, observa Danowski ${ }^{84}$,

${ }^{80}$ LEIBNIZ, "Carta a Sofia, 4 de novembro de 1696", Apud. DANOWSKI, Leibniz e as voltas do tempo, p. 115.

81 DANOWSKI, Leibnize as voltas do tempo, p. 118.

82 LEIBNIZ, Textes inédits, p. 95.

${ }^{83}$ LEIBNIZ, "De rerum originatione radicali", CEuvres choisies, $\$ 16$.

${ }^{84}$ DANOWSKI, Leibnize as voltas do tempo, p. 111. 
Leibniz afirma poder concluir que a espécie humana não permanecerá sempre no estado em que se encontra, porque não é conforme a harmonia divina fazer vibrar sempre a mesma corda. Mas, o aperfeiçoamento dos homens não será necessariamente direto e numa única direção. Deve-se antes crer, pensa Leibniz, segundo as razões naturais da congruência, que as coisas devem avançar em direção ao melhor, seja pouco a pouco, seja algumas vezes por saltos. Isso pode parecer desmentir o que se acabara de afirmar, mas o que Leibniz entende por aperfeiçoamento por saltos é o aperfeiçoamento que se dá após momentos de recuo, ao modo como nós às vezes recuamos para melhor saltar. ${ }^{85} \mathrm{O}$ movimento do saber é, sem dúvida, o esclarecimento restituído que as novas aquisições trazem para o conjunto, no início incapaz de ser analisado, confuso, um dado infinitamente complexo: "Sou obrigado, as vezes, a comparar nossos conhecimentos a um grande armazém, ou a uma loja, um balcão sem ordem e sem inventário, porquanto não sabemos aquilo que já possuímos e, por isso mesmo, não podemos deles nos servir em caso de necessidade." ${ }^{86} \mathrm{O}$ progresso consiste, não em possuir cada vez mais, porém em ordenar sempre mais, isto é, em sistematizar melhor os conhecimentos e não em adicioná-los. Ele não se reduz a um quadro de conquistas sucessivas do saber teórico que aguarda sua aplicação igualmente eficiente. Para além de uma novidade, convêm falar em renovação antes de acúmulo.

Nisto, nosso filósofo se distingue daqueles que o precederam. Os acontecimentos futuros já encontravam registro especulativo em Aristóteles: dizia-se, por um lado, daquilo que deve acontecer necessariamente; por outro, referia-se àquilo que é pensado sob a forma do futuro. ${ }^{87}$ Os escolásticos apropriaram-se desses dois aspectos e cunharam as expressões futura necessária e futura contingentia referindo-se a cada um deles, respectivamente. A expressão futuros contingentes conservou-se mais usual, segundo Lalande ${ }^{88}$. "Hoje", diz Leibniz, "os filósofos estão de acordo que a verdade dos futuros contingentes é determinada, quer dizer, os futuros contingentes são futuros, ou que eles serão, acontecerão, porque é igualmente seguro que o passado foi." ${ }^{89}$ Unida aos futuros contingentes, Leibniz refere-se, ainda, a uma noção aglutinadora e responsável pela unificação superior das obras divinas, ou seja, uma noção capaz de apresentar-se como uma espécie de protogênese do que entendermos mais tarde como progresso: "Para que a beleza e a perfeição universais das obras de Deus atinjam seu mais alto degrau, todo o universo, é preciso reconhecer, progride perpetuamente e com inteira liberdade, de sorte que ele avança sempre em direção a uma civilização superior." ${ }^{\circ 0}$ A noção de progresso não deve ser limitada a um aperfeiçoamento das técnicas, mas, na verdade, se estabelece como um progressus in infinitum, marcha do espírito que, sendo dadas certas condições, passa necessariamente de cada termo a um termo novo; por exemplo, na sequência dos números, ou ainda na busca de causas eficientes. Neste sentido, pode-se falar mesmo em quantitas progressus (segundo uma dada direção AB): "produto da massa de um

85 Cf. LEIBNIZ, De l'Horizon de la Doctrine Humaine: Apokatastasis pantwn (la restitution universelle). Paris: Vrin, 1991.

86 LEIBNIZ, "Discours touchant la méthode de la certitude et l'art d'inventer", Die philosophischen Schriften (Band VII), p. 178.

87 Cf. ARISTOTE. De interpretacione. cap. IX.

88 Cf. LALANDE, Vocabulaire technique et critique de la Philosophie (Article Futurs). Paris: PUF, 1926.

89 LEIBNIZ, "Essais de théodicée”, \$36, p. 132.

90 LEIBNIZ, "De la production des choses”, p. 191. 
corpo pela sua velocidade segundo A B." 91 Tudo isso se dá, porque "a consciência é uma lenta sistematização, o desvendamento da unidade orgânica do saber." "92

\section{4. À guisa de conclusão}

É verdade que Leibniz opõe o "destino dos maometanos", que comandaria uma submissão passiva ao real sem tentar compreendê-lo, ao "destino dos cristãos", que supõe o mundo possuidor de um sentido - o dever do homem consiste em sua busca e afirmação. Ora, esse prisma associa-se a certa capacidade de iniciativa do espírito, asseguradora de seu desenvolvimento: "nossa felicidade não consistirá jamais, nem deve consistir, num pleno gozo pelo qual não se teria mais nada a desejar e que tornaria nosso espírito estúpido, mas num progresso perpétuo voltado a novos prazeres e a novas perfeições." 93 O progresso, assim constituído, parece indicar uma afirmação objetiva do homem, enquanto sujeito cognoscitivo e espiritual, na imanência da história. Contrariamente a Bossuet ${ }^{94}$, Leibniz não considera tal objetivação sinônimo de corrupção. Para aquele, os vetores que indicam um sentido para a história permanecem retirados dos desígnios de Deus, criador e mantenedor do universo. O ascetismo defendido pelo autor do Discours sur l'bistoire universelle não exige somente do indivíduo, chamado a sacrificar, em sua própria individualidade, a carne ao espírito, a riqueza material à vida eterna; ele se aplica também à existência coletiva, donde as finalidades materiais devem submeter-se à Lei sob o controle da Igreja. Com efeito, os valores políticos e econômicos, sociais e culturais, em sua relatividade, não podem ter significação em si mesmos, eles são desprovidos de bom senso se analisados de per si. A caminhada na sequência das épocas tem por objetivo descortinar os ditames maiores para o resgate da humanidade. Efetivamente, Leibniz encontra-se afastados de vários desses pontos assumidos no Discours. Todavia, essas duas grandes e distintas expressões do século XVII traçam as linhas mestras para a discussão acerca da história e do progresso, que marcam seu período. Embora em campos opostos, os dois pensadores possuem algo em comum: a defesa da fé cristã.

Cristão, Leibniz considera o homem como ser histórico, inserido na Universal Histori. Entretanto, a fé cristã acredita que o homem não possui a liberdade que reclamam as decisões históricas. Sou sempre determinado pelo meu passado, ele faz de mim o que sou, dele não posso me libertar e, ao fim e ao cabo, embora inconscientemente, não quero, na verdade, me libertar. Ninguém aceita renegar-se sem reservas. Cada homem é cônscio de suas responsabilidades e possui certa liberdade na hora de escolher. Todavia, se reconhece que sua liberdade é somente relativa, confessa, por isso mesmo, que limita sua liberdade e que é marcado pelo seu passado. Ser completamente livre significaria, para ele, ser livre de si mesmo. O homem que compreende sua historicidade radicalmente, o homem que se compreende radicalmente, em outros termos, o homem que compreende seu eu autêntico como devir, necessita saber que só pode recebê-lo como um dom do futuro. De ordinário,

\footnotetext{
${ }^{91}$ LEIBNIZ, “Carta a Bernoulli, 28 de janeiro de 1696”, Commercium epistolicun, I, p.125.

92 COURTÈS, "La conception leibnizienne du progrès", p. 38.

93 LEIBNIZ, "Principes de la Nature et de la Grâce", \ 18.

94 Cf. BOSSUET, Discours sur l'histoire universelle. Ed. Jacques Trucher. Paris: Garnier-Flammarion, 1966.
} 
o homem luta para dispor de seu futuro. A sua própria condição histórica para lá o incita, porque ela contém sua responsabilidade face ao futuro. Com efeito, essa responsabilidade faz nascer no homem a ilusão de que ele pode dispor de seu futuro. Porém, nessa ilusão o homem permanece o "velho homem"95 - aquele acorrentado a seu passado. Ele não compreende que apenas o homem radicalmente livre pode assumir suas responsabilidades. Não vê que não carece da busca insistente da segurança, mesmo aquela de uma lei moral, capaz de suprimir ou de transformar suas responsabilidades. O homem deve ser livre ou tornar-se livre perante si mesmo. Mas não deve espera tal liberdade por meio de sua vontade ou de suas próprias forças, assim pensando, continuará aprisionado na condição de "velho homem". Ele pode unicamente receber essa liberdade e a receber como um dom. ${ }^{96}$ Todas as ações, voluntárias ou não, se realizam em virtude de um plano divino, de um destino interior que cada um executa por meio de decisões inteiramente previsíveis, em correspondência programada e orquestrada por Deus com todas as outras numa comunicação sem interação. A implicação prática pode ser resumida à forma de fatalismo sereno ${ }^{97}$. Não se trata de desesperar, mas de aceitar a necessidade de maneira tranquila ao tomar consciência de que somos guiados para o melhor quando permanecemos confiantes na providência. "E, por conseguinte, todas as vezes que uma coisa nos pareça repreensível nas obras de Deus, é preciso entender que nós não a conhecemos o suficiente, e crer que um sábio, que a compreendesse, julgaria que não podemos mesmo desejar nada de melhor." 98

O progresso universal, concebido a partir de uma irremediável crença na providência, ou seja, a partir do otimismo, é o fundamento para que se afirme: uma das principais utilidades da história é servir à religião e à teologia cristãs. A história, e o progresso a ela conexo, não tem sua fonte unicamente nas forças do espírito humano - colocadas a serviço de uma sociedade melhor; ela une-se, de início, ao pertencimento do homem à natureza e ao mundo, o que lhe faz imergir numa atmosfera de inquietude devido à impossibilidade que a finitude traduz. Consequência: a visão do passado inspira o entendimento a decifrar os enigmas que lhe são posto em desafio, como uma espécie de alento transposto para as cenas históricas pela interferência da bondade providencial.

A partir desse ponto de vista a associação entre otimismo e progresso ganha a marca cristã, ou seja, a entrega irrestrita da condução da história às mãos exteriores, ao que está fora da própria história. Sem embargo, os homens não podem escolher seu ponto de partida, mas podem fixar-se um alvo, esperar atingi-lo e escolher um caminho sobre o qual desejam seguir. Isso é possível até certo ponto, eis o que sempre pensaram. Compreenderam que dependiam das circunstâncias e que deviam lutar contra potências adversas, com frequência mais fortes do que eles, para realizar seus planos de vida. Descobriram que não são somente suas ações que fazem a história, mas, do mesmo modo, o destino, a providência: "Este romance da vida

95 Epístola aos Efésios 4, 22-24. Deponere vos secundum pristinam conversationem veterem hominem, qui corrumpitur secundum desideria erroris. Renovamini autem spiritu mentis vestrce, et induite novum hominem, qui secundum Deum creatus est in justitia, et sanctitat e veritatis (Despojai-vos do velho homem, que se corrompe com os desejos enganosos, renovai-vos pela transformação espiritual de vossas mentes e revistaisvos do novo homem, criado segundo Deus em verdadeira justiça e santidade).

96 Cf. BULTMANN, Histoire et eschatologie, p. 200-201.

${ }^{7}$ Cf. MALKASSIAN, Candide: un débat philosophique - La critique de Leibnizpar Voltaire, p. 26.

98 LEIBNIZ, "Essais de théodicée”, La cause de Dieu \47, p. 442. 
humana, que faz a história universal do gênero humano, encontra-se inteiramente concebido no entendimento divino junto a uma série de outros, (...) a vontade de Deus somente a ele outorgou a existência porque essa sequência de acontecimentos deveria, com o restante das coisas, convir de modo ótimo para resultar o melhor." ${ }^{99}$ Uma teoria acerca da melhor das histórias humanas possíveis: eis o resultado que podemos atribuir à teodicéialeibniziana. A descoberta desse uso ótimo baseado num arranjo causal, ao compor um discurso sobre a história, desencadeará um longo e frutífero debate no século XVIII e comporá o centro da gênese da formulação da filosofia da história.

\section{LEIBNIZ AND HISTORY}

Abstract: Generally, the author of Monadology is not studied on the basis of a philosophical interest in history. However, his intellectual concerns are addressed to this domain, and some philosophies of history had the Essais de théodicée (1710) in their horizons, although Leibniz did not write a theodicy of history. This paper aims to put forward some perspectives about the Leibnizian thought regarding that field, with emphasis on the bond between men's trajectory and theological basis, in order to understand how these two elements are articulated to justify optimism as a decisive analytical framework for an idea of history.

Keywords: Leibniz - history - theology - optimism.

\section{REFERÊNCIAS BIBLIOGRÁFICAS}

ARISTOTE. De interpretacione. Trad. de Tricot. Paris: Vrin, 1959.

Trad. de J. Tricot. Paris: Vrin, 1953.

BELAVAL, Y. Histoire de la philosophie. Paris: Gallimard, 1973.

Leibniz, critique de Descartes. Paris: Gallimard, 1960.

BINOCHE, B. "Les histoires d'avant l'histoire". In: BINOCHE, B. et TINLAND, F. (orgs.)

Sens du devenir et pensée de l'bistoire au temps des Lumières. Seyssel: Champ Vallon, 2000.

Les trois sources des philosophies de l'bistoire(1764-1798). Paris: PUF, 1994.

BOSSUET. Discours sur l'histoire universelle. Ed. Jacques Trucher. Paris: Garnier-Flammarion, 1966.

BULTMANN, R. Histoire et eschatologie. Trad. de R. Brandt. Neuchâtel: Delachaux et Niestlé, 1959.

COURTÈS, H. "La conception leibnizienne du progrès". In: BINOCHE, B. et TINLAND, F. (orgs.). Sens du devenir et pensée de l'histoire au temps des Lumières. Seyssel: Champ Vallon, 2000.

99 LEIBNIZ, "Essais de théodicée”, \$149, p. 208. 
DANOWSKI, Déborah. "Leibniz e as voltas do tempo". In: Revista Dois Pontos, v. 2, n. ${ }^{\circ}$, outubro, 2005.

DAVILLÉ, L. Leibniz historien: essai sur l'activité et la méthode historiques de Leibniz. Paris: Félix Alcan, 1909.

DELBOS, V. La philosophie pratique de Kant. Paris: Félix Alcan, 1905.

DESCARTES, R. CEurres de Descartes. Publiées par C. Adam \& P. Tannery. Paris: Vrin, 1974.

Cuvres Philosophiques. Textes établis, présentés et annotés par Ferdinand Alquié.

Paris: Garnier, 1967.

GUSDORF, G. "L'homme des Lumières”. In: KOVÁCS, I. Les Lumières en Hongrie, en Europe Centrale et en Europe Orientale. Budapest: Maison d'Édition de l'Academie des Sciences de Hongrie; Paris: Éditions CNRS, 1984.

HAZARD, P. La crise de la consciente européenne. Paris: Fayard, 1961.

LALANDE, A. Vocabulaire technique et critique de la Philosophie (Article Futurs). Paris: PUF, 1926.

LEIBNIZ. Carta a Sofia, 4 de novembro de 1696. Apud. DANOWSKI, Déborah. "Leibniz e as voltas do tempo". In: Revista Dois Pontos, vol.2, no 1, p. 115, outubro, 2005.

- "Comment distinguer les phénomènes réels des imaginaires". In: Discours de Métaphysique et autres textes. Paris: Flammarion, 2001.

Commercium epistolicun, I. Ed. Gruber. Hannover, 1745.

Correspondência com Clarke. Trad. Carlos Lopes de Matos. Coleção Os Pensadores. São Paulo: Abril Cultural, 1979.

. "De la production des choses". In: Opuscules philosophique schoisis. Paris: Vrin, 2001.

Vrin, 1991.

De l'Horizon de la Doctrine Humaine: Apokatastasis pantwn (la restitution universelle). Paris:

- Die philosophischen Schriften. Edição de C. I. Gerhardt. Hildesheim: Georg OlmsVerlag, 1978.

"Discours de métaphysique". In: Discours de Métaphysique et autres textes. Paris: Flammarion, 2001.

“Essais de théodicée”. In: Oeuvres de Leibniæ: Paris: Charpentier, 1846.

Gesammelte Werke: Geschichte. Hildesheim: Georg OlmsVerlagsbuchhandlung, 1966.

Leibniz - Thomasius Correspondance 1663-1672. Trad. de R. Bodéüs. Paris: Vrin, 1993. 
. "Monadologie". In: Principes de la Nature et de la Grâce, Monadologie et autres textes (17031716), Paris: Flammarion, 1996.

. Nouveaux essais sur l'entendement humain. Paris: Garnier-Flammarion, 1990.

. "Nouvelles ouvertures". In: Opuscules et fragments inédits de Leibniæ. Ed. L. Couturat. Paris: Félix Alcan, 1903.

. Cuvres choisies. Paris: Aubier Montaigne, 1972.

. Opera omnia. Edição L. Dutens, Genebra, 1768/reimpresso. Hildesheim: Olms, 1989.

. Opuscules et fragments inédits de Leibniz. Ed. L. Couturat. Paris: Félix Alcan, 1903.

. Opuscules philosophique schoisis. Paris: Vrin, 2001.

Pensée de Leibniz sur la religion et la morale (Tome I). Bruxelles: Societé nationale pour la propagation des bons livres, 1838.

"Principes de la Nature et de la Grâce". In: Principes de la Nature et de la Grâce, Monadologie et autrestextes (1703-1716).

Principes de la Nature et de la Grâce, Monadologie et autres textes (1703-1716). Paris: Flammarion, 1996.

Schriftenund Briefe zur Geschichte. Edição de M-L Babin e G. van den Heuvel. Hannover: Verlag Hahnsche Buchhandlung, 2004.

Sistema novo da natureza e da comunicação das substâncias e outros textos. Trad. Edgard Marques. Belo Horizonte: Editora da UFMG, 2002.

LOPES DOS SANTOS. Luiz Henrique. "Leibniz e os futuros contingentes". In: ANALYTICA, 1 (3), 1998.

MALKASSIAN, G. Candide: un débat philosophique - La critique de Leibniz, par Voltaire. Paris: Ellipses, 2005.

MARQUES, Edgar. Apresentação. In: Leibniそ, Sistema novo da natureza e da comunicaşão das substâncias e outros textos. Trad. Edgard Marques. Belo Horizonte: Editora da UFMG, 2002.

PLATÃO. "Timée". In: Euvres Complètes. Trad. de L Robin, Bibliothèque de la Pléiade. Paris: Gallimard, 1990. 